\title{
Factors controlling gully development: Comparing continuous and discontinuous gullies
}

J.J. Le Roux* and P.D. Sumner

Department of Geography, Geoinformatics and Meteorology

University of Pretoria

Pretoria 0002

${ }^{*}$ Current address: Institute for Soil, Climate and Water

Agricultural Research Council

Private Bag X79

Pretoria 0001

To whom all correspondence should be addressed.

Tel No: +2712 310-2684; Fax No: +2712 323-1157;

E-mail: LeRouxJ@arc.agric.za

\section{Abstract}

Gully erosion is a degradation process affecting soils in many parts of the World. Despite the complexity of a series of collective factors across different spatial scales, previous research has not yet explicitly quantified factor dominance between different sized gullies. This factorial analysis quantifies the differences in factor dominance between continuous and discontinuous gullies. First, gullies (totaling 5273 ha) visible from SPOT 5 imagery were mapped for a catchment (nearly $5000 \mathrm{~km}^{2}$ ) located in the Eastern Cape Province of South Africa. Eleven important factors were integrated into a geographical information system including topographical variables, parent material-soil associations and land usecover interactions. These were utilized in a zonal approach in order to determine the extent factors differ between continuous and discontinuous gullies. Factors leading to the development of continuous gullies are gentle footslopes in zones of saturation along drainage paths with a large contributing area, erodible duplex soils derived from mudstones, and poor vegetation cover due to overgrazing. Compared to continuous gully conditions, more discontinuous gullies occur on rolling slopes where the surface becomes less frequently saturated with a smaller contributing area, soils are more stable and shallow. Factorial analysis further illustrates that differences in factor dominance between the two groups of gullies is most apparent for soil factors. A combination of overgrazing and susceptible mudstones proves to be key factors that consistently determine the development of continuous and discontinuous gullies.

Key Words: Gully erosion, continuous, discontinuous, factor dominance. 


\section{Introduction}

Gully erosion is a major soil degradation problem, confronting both land and water resource management in many parts of the World (e.g. Descroix et al., 2008; Kheir et al., 2008; Kakembo et al., 2009). It is a process where surface (or subsurface) water concentrates in narrow flow paths and removes the soil resulting in incised channels that are too large to be destroyed by normal tillage operations (Kirkby and Bracken, 2009). Although gully erosion is a natural process, it is most often triggered or accelerated by human activities such as clearing vegetation and overstocking (Valentin et al., 2005). Once initiated, individual gullies can expand into a network of active gullies that contribute significantly to soil loss in a catchment (e.g. Martinez-Casasnovas et al., 2003). In addition to the loss of arable land, the eroded material leads to sedimentation of reservoirs, as well as lower water tables reducing water available for plant growth or livestock (Kirkby and Bracken, 2009). To prevent these negative impacts and to remediate affected areas (which can be very costly), the spatial extent of the problem and the factors causing it should be established, followed by regional-based erosion control strategies (Poesen et al., 2003; Tamene et al., 2006).

Most regional studies across the globe emphasize the sheet and rill aspects of the erosion cycle, but few map and/or model gully erosion (e.g. Martinez-Casasnovas, 2003; Vrieling et al., 2007). Perspectives on gully factors have typically been obtained from field scale $\left(<10^{-1} \mathrm{~km}^{2}\right)$ studies and are confined to local conditions (Vrieling, 2006; Ndomba et al., 2009). This is probably due to the temporal and spatial complexity at which the phenomenon occurs since several factors contribute to gully development including topographical variables, parent material-soil associations and land use-cover interactions (Valentin et al., 2005). Furthermore, gully contributing factors important in a specific area are not necessarily important in other areas (Sonneveld et al., 2005). For example, a factorial analysis by Descroix et al. (2008) in the subtropical mountain slopes of Western Sierra Madre underline the separation of gullies in two groups. The first group consists of large gullies on gentle slopes with extended contributing/catchment areas where soils are thick and stone-free. The second group constitutes small gullies that occur mainly on hillslopes characterized by steep slopes with thin and stony soils. However, only a 
qualitative appreciation of the factors influencing their development has been obtained and the factors distinctively controlling small and large gully development remain poorly understood. Differences in factor dominance between large continuous gullies with a branching network that discharges into a stream/river at the base of a slope and small discontinuous that fade out into a depositional zone have not yet been fully resolved.

In this context, the aim of the study is to quantify the differences in factor dominance between continuous gullies (cgs) and discontinuous gullies (dgs). This will be achieved by accurately mapping gullies in a large catchment (nearly $5000 \mathrm{~km}^{2}$ ) followed by integrating a variety of ancillary information in the form of spatial data layers, also referred to as gully factor maps, into a geographical information system (GIS). A specific catchment located in the Eastern Cape Province of South Africa is used for this purpose coded as tertiary catchment 35 by the South African Department of Water Affairs. The catchment was chosen for its high erosion risk on high potential agricultural land (Le Roux et al., 2008a; b). The study highlights gully factors likely to emerge as dominant between cgs and $d g s$ and provides insight regarding the interplay of eleven important causal factors, collectively disregarded in previous research. The implications of the results are also outlined to assist the design of appropriate strategies targeted at area-specific management of the major causative factors of gully erosion, including the formulation of preventative measures in susceptible areas. Temporal scales are beyond the scope of this research and the study does not distinguish between active and passive gullies.

\section{Site description}

The catchment lies between $30^{\circ} 46^{\prime} 58^{\prime \prime}$ and $31^{\circ} 28^{\prime} 55^{\prime \prime}$ south and $27^{\circ} 55^{\prime} 56^{\prime \prime}$ and $29^{\circ} 13^{\prime}$ 47" east in the Eastern Cape Province of South Africa, north of the town Mthatha (formerly Umtata) (see Figure 1). Elevation ranges from $168 \mathrm{~m}$ at the catchment outlet in the southeast to $2730 \mathrm{~m}$ in the Drakensberg mountains. The catchment area of $4924 \mathrm{~km}^{2}$ is drained mainly by the Tsitsa River, which flows into the Mzimvubu River after a flow length of approximately $200 \mathrm{~km}$ from northwest to southeast. Landforms are complex, ranging from very steep (40\%) mountain slopes of the Drakensberg to gently undulating footslopes $(2 \%)$ and nearly level valley floors. The climate is sub-humid with mean annual rainfall ranging from $672 \mathrm{~mm}$ in the lower plains to $1327 \mathrm{~mm}$ in the mountains. Vegetation is 
largely influenced by altitude, as well as by grazing and burning. The catchment is mainly dominated by grassland including montane, subalpine and alpine belts with pockets of shrub and woodland or Protea savannah (Killick, 1963 as cited in Flügel et al., 2003; Low and Rebelo, 1998). According to the National Land Cover (2000), natural vegetation covers approximately $3400 \mathrm{~km}^{2}(70 \%)$ of the catchment area. The main land use is subsistence grazing (540 $\mathrm{km}^{2}$ or $11 \%$ of the catchment) with minority land uses including forest plantations $(4.3 \%)$ and commercial agriculture $(1.2 \%)$. The geology consists of a succession of Beaufort Group sedimentary layers of the Permian Age (Council for Geoscience, 2007). Adelaide mudrock is succeeded by various layers of sedimentary deposits including Tarkastad Mudstones and alternating sandstones of the Molteno, Elliot and Clarens Formations with overlying Drakensberg basaltic lava. Soils from the Tarkastad and Molteno Formations in the central part of the catchment are associated with duplex soils (Land Type Survey Staff, 1972-2008) that are highly erodible with widespread gully erosion evident (Le Roux et al. 2008a).

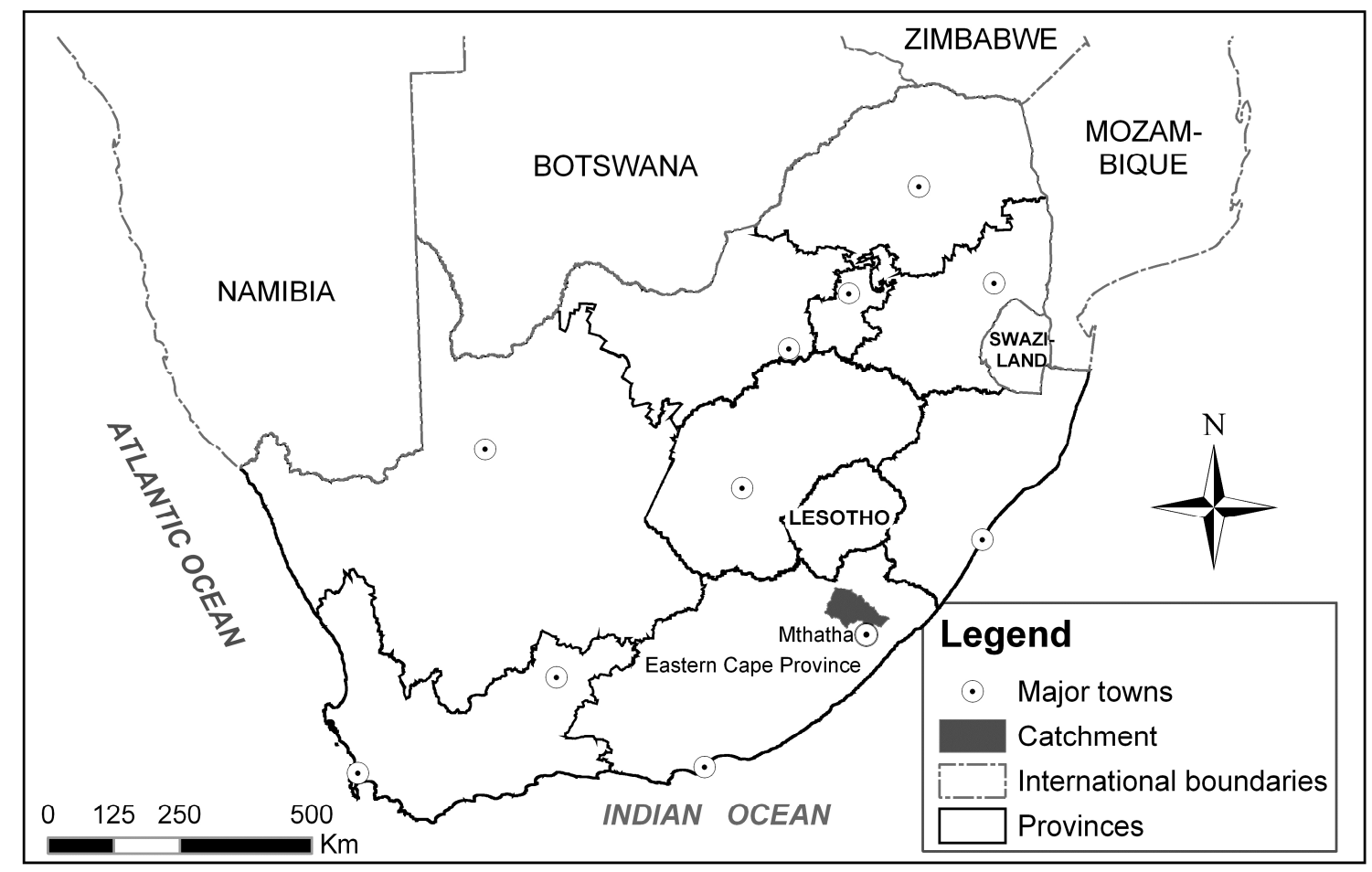

Figure 1: Location map of study area in the Eastern Cape Province, South Africa. 


\section{Methodology: Gully mapping and factorial analysis}

Gully erosion mapping was based on analysis of SPOT 5 imagery from various acquisition dates in 2008. SPOT 5 satellite imagery was utilized because the panchromatic sharpened images at $2.5 \mathrm{~m}$ resolution provides high resolution air photo-like quality for gully mapping (Taruvinga, 2008) and was acquired from government agencies for the whole of South Africa. The study resolved to map gully erosion for the whole catchment by means of manual vectorization at a scale of 1:10 000. Although the technique is time-consuming, automated mapping techniques could not express individual gullies with the required accuracy due to their spectral complexity over such a large area. Subsequently, the study effectively distinguished between large continuous gullies (cgs) with a branching network that discharges into a stream/river at the base of a slope and relatively small discontinuous gullies (dgs) that fade out into a depositional zone.

Several factors contribute to gully development and they have been well described in the literature, including topographical variables (e.g. Desmet et al., 1999; Kheir et al., 2007; Kakembo et al., 2009), parent material-soils interactions (e.g. Laker, 2004; Valentin et al., 2005) and cover management (e.g. Boardman and Foster, 2008; Gutiérrez et al., 2009). The study considered incorporation of rainfall since it is known to be and important driving factor in gully development (Kirkby and Bracken, 2009). Although rainfall varies from 672 $\mathrm{mm}$ in the plains to $1327 \mathrm{~mm}$ in the mountains, it was not integrated in this analysis as it does not vary substantially in the central gullied part of the catchment. Since not all gully factors can be taken into account at a regional scale, the study considered incorporation of the most important factors for which regional data already existed, or that could be readily derived for the whole catchment. Descriptions of the gully contributing factors, methods of derivation and data sources are summarized in Table 1. Furthermore, each gully factor layer was categorized into 5 expert-based rankings or classes that, according to observations, uniquely influence gully development. The soil depth factor was categorized into only 3 classes, mainly due to the unavailability of such spatial data (Van Den Berg and Weepener, 2009). These classes allowed assessment of the separate effects of different factors and spatially weighted comparison of environments with unequal surface areas within the catchment, as well as comparison between numerical (S, AS, TWI, LS, K and VC) and non-numerical (TU, GT, LT, SD and LU) data (see Table 1). 
Table 1: $\quad$ Description of gully contributing factors and methods of derivation.

\begin{tabular}{|c|c|c|c|c|c|}
\hline \multirow{2}{*}{$\begin{array}{l}\text { Contribu- } \\
\text { ting factor }\end{array}$} & \multicolumn{5}{|c|}{ Description and method of derivation } \\
\hline & $\begin{array}{c}\text { Class } 1 \\
\text { range }\left(\text { area- } \mathrm{km}^{2}\right)\end{array}$ & $\begin{array}{c}\text { Class } 2 \\
\text { range }\left(\text { area- } \mathrm{km}^{2}\right)\end{array}$ & $\begin{array}{c}\text { Class } 3 \\
\text { range }\left(\text { area- } \mathrm{km}^{2}\right)\end{array}$ & $\begin{array}{c}\text { Class } 4 \\
\text { range }\left(\text { area- } \mathrm{km}^{2}\right)\end{array}$ & $\begin{array}{c}\text { Class } 5 \\
\text { range }\left(\text { area- }-\mathrm{km}^{2}\right)\end{array}$ \\
\hline \multirow[t]{2}{*}{ Slope (S) } & \multicolumn{5}{|c|}{$\begin{array}{l}\text { Gradient (in \%) extracted from } 20 \text { m resolution DEMs (GISCOE, 2001) using the Deterministic } \\
\text { Infinity (D-Inf) multiple flow algorithm in TauDEM (Tarboton, 2004) in ESRI's ArcGIS }\end{array}$} \\
\hline & $0-5.00(1105)$ & $5.00-10.0(1105)$ & $10.0-19.0(989)$ & $19.0-34.0(873)$ & $34.0-100(852)$ \\
\hline \multirow{2}{*}{$\begin{array}{l}\text { Upslope } \\
\text { contributing } \\
\text { area (AS) }\end{array}$} & \multicolumn{5}{|c|}{$\begin{array}{l}\text { Upslope area per unit width of contour (in } \mathrm{m}^{2} \text { ) extracted from above-mentioned } 20 \mathrm{~m} \text { resolution } \\
\text { DEMs using the D-Inf multiple flow algorithm in TauDEM }\end{array}$} \\
\hline & $0-100(1598)$ & $100-200(1297)$ & $200-400(1037)$ & $400-800(502)$ & $>800(462)$ \\
\hline \multirow{2}{*}{$\begin{array}{l}\text { Topographic } \\
\text { wetness } \\
\text { index (TWI) }\end{array}$} & \multicolumn{5}{|c|}{$\begin{array}{l}\text { Using TauDEM, zones of saturation is predicted along drainage paths where AS is high and S is } \\
\text { low; assuming steady-state and uniform soil conditions (transmissivity) (Wilson and Gallant, 2000) }\end{array}$} \\
\hline & $0-0.36(866)$ & $0.36-0.39(939)$ & $0.39-0.42(984)$ & $0.42-0.46(1039)$ & $0.46-1.00(1066)$ \\
\hline \multirow{2}{*}{$\begin{array}{l}\text { Sediment } \\
\text { transport } \\
\text { capacity } \\
\text { index (LS) }\end{array}$} & \multicolumn{5}{|c|}{$\begin{array}{l}\text { LS is the spatial distribution of soil loss potential that is equivalent to the length-slope factor in the } \\
\text { RUSLE where both AS an S is high; assuming the erosion rate is transport limited with uniform } \\
\text { rainfall excess runoff (Mitasova et al., 1996). }\end{array}$} \\
\hline & $0-1.02(1110)$ & $1.02-2.30(1080)$ & $2.30-3.98(976)$ & $3.98-6.85(885)$ & $6.85-12.6(874)$ \\
\hline \multirow{2}{*}{$\begin{array}{l}\text { Terrain unit } \\
\text { (TU) }\end{array}$} & \multicolumn{5}{|c|}{$\begin{array}{l}\text { Five terrain morphological areas mapped/modelled from a } 90 \mathrm{~m} \text { SRTM DEM (Rodriguez et al., } \\
\text { 2005) interpolated to } 30 \mathrm{~m} \text {, using typical topographical algorithms of Evans (1979) and Schmidt et } \\
\text { al. (2003) in combination with manual vectorization (Van den Berg and Weepener, 2009) }\end{array}$} \\
\hline & $\begin{array}{l}\text { Crest } \\
(351)\end{array}$ & $\begin{array}{c}\text { Convex } \\
\text { midslope }(2284)\end{array}$ & $\begin{array}{c}\text { Concave } \\
\text { midslope (2062) }\end{array}$ & $\begin{array}{l}\text { Footslope } \\
(178)\end{array}$ & $\begin{array}{l}\text { Valley floor } \\
\text { (87) }\end{array}$ \\
\hline \multirow[b]{2}{*}{$\begin{array}{l}\text { Geology } \\
\text { type (GT) }\end{array}$} & \multicolumn{5}{|c|}{ Stratigraphic/lithologic polygon descriptions at a 1:250 000 scale (Council for Geoscience, 2007) } \\
\hline & $\begin{array}{l}\text { Drakensberg } \\
\text { basalt, Karoo } \\
\text { dolerite }(777)\end{array}$ & $\begin{array}{l}\text { Elliot mudstones, } \\
\text { subordinate } \\
\text { sandstone (779) }\end{array}$ & $\begin{array}{l}\text { Molteno } \\
\text { sandstones } \\
\quad(1571)\end{array}$ & $\begin{array}{l}\text { Alluvium, } \\
\text { mudrock, fine- } \\
\text { grained } \\
\text { sandstone (595) }\end{array}$ & $\begin{array}{l}\text { Tarkastad } \\
\text { mudstones } \\
\quad(1204)\end{array}$ \\
\hline \multirow[b]{2}{*}{$\begin{array}{l}\text { Land type } \\
\text { (LT) }\end{array}$} & \multicolumn{5}{|c|}{$\begin{array}{l}\text { A class of land over which macroclimate, terrain form, and soil pattern each display a marked } \\
\text { degree of uniformity at a 1:250 } 000 \text { scale (Land Type Survey Staff, 1972-2008) }\end{array}$} \\
\hline & $\begin{array}{l}\text { Variety of } \\
\text { relatively stable } \\
\text { soils } \\
(304)\end{array}$ & $\begin{array}{l}\text { Variety of } \\
\text { moderately } \\
\text { stable soils } \\
(1889)\end{array}$ & $\begin{array}{c}\text { Variety of } \\
\text { moderately } \\
\text { erodible soils } \\
(1063)\end{array}$ & $\begin{array}{c}\text { Variety of } \\
\text { erodible, shallow } \\
\text { soils with minimal } \\
\text { development } \\
(706)\end{array}$ & $\begin{array}{c}\text { Highly erodible, } \\
\text { strongly } \\
\text { structured, } \\
\text { duplex soils } \\
(574) \\
\end{array}$ \\
\hline \multirow[t]{2}{*}{$\begin{array}{l}\text { Soil } \\
\text { erodibility } \\
\text { factor (K) }\end{array}$} & \multicolumn{5}{|c|}{$\begin{array}{l}\text { Using the SLEMSA model of Elwell (1976), erodibility units were established and used as a guide } \\
\text { to the assignment of USLE (Wischmeier and Smith, 1978) K-factors (in SI units t/ha per unit } \\
\text { 'erosivity') to land types at a 1:250 } 000 \text { scale (Le Roux et al., 2008b) }\end{array}$} \\
\hline & $0-0.20(367)$ & $0.20-0.25(588)$ & $0.25-0.30(1530)$ & $0.30-0.35(1564)$ & $0.35-0.70(871)$ \\
\hline \multirow[t]{2}{*}{$\begin{array}{l}\text { Soil depth } \\
\text { (SD) }\end{array}$} & \multicolumn{5}{|c|}{$\begin{array}{l}\text { Soil depth was obtained from existing point (753) datasets of the ARC-ISCW, utilized in scripting } \\
\text { rules (outside the scope of the text) to create three soil depth class boundaries at a 1:50 000 } \\
\text { scale that spatially correlate with land type data (Van den Berg and Weepener, 2009) clarity }\end{array}$} \\
\hline & Shallow (813) & Medium (2140) & Deep (1930) & n.a. & n.a. \\
\hline \multirow[b]{2}{*}{$\begin{array}{l}\text { Land use } \\
\text { (LU) }\end{array}$} & \multicolumn{5}{|c|}{$\begin{array}{l}\text { National Land Cover database of South Africa derived from Landsat TM imagery with a grid cell } \\
\text { resolution of } 30 \mathrm{~m} \text { (National Land Cover, 2000) }\end{array}$} \\
\hline & $\begin{array}{l}\text { Natural } \\
\text { vegetation and } \\
\text { plantations } \\
(3884)\end{array}$ & $\begin{array}{l}\text { Urban / Built-up } \\
\text { inc. 'townships' } \\
\quad(142)\end{array}$ & $\begin{array}{l}\text { Cultivated, } \\
\text { commercial, } \\
\text { irrigated and } \\
\text { dryland (76) }\end{array}$ & $\begin{array}{l}\text { Cultivated, } \\
\text { subsistence, } \\
\text { dryland } \\
(282)\end{array}$ & $\begin{array}{l}\text { Degraded } \\
\text { unimproved and } \\
\text { natural grassland } \\
(541)\end{array}$ \\
\hline \multirow[t]{2}{*}{$\begin{array}{l}\text { Vegetation } \\
\text { cover (VC) }\end{array}$} & \multicolumn{5}{|c|}{$\begin{array}{l}\text { Fractional vegetation cover (in \%) derived from TSAVI on Landsat TM image with a grid cell } \\
\text { resolution of } 30 \mathrm{~m} \text {; delivers reliable vegetation cover results for arid and semi-arid grassveld } \\
\text { landscapes in South Africa (Flügel et al., 2003) }\end{array}$} \\
\hline & $0-20.0(897)$ & $20.0-30.0(987)$ & $30.0-40.0(1115)$ & $40.0-50.0(928)$ & $50.0-100(903)$ \\
\hline
\end{tabular}

(R)USLE - (Revised) Universal Soil Loss Equation; SLEMSA - Soil Loss Estimator of Southern Africa; SRTM Shuttle Radar Topography Mission; TauDEM - Terrain Analysis Using Digital Elevation Models; ARC-ISCW ARC-Institute for Soil, Climate and Water; TSAVI - Transformed Soil Adjusted Vegetation Index. 
A challenge was to assess how factor dominance differs between continuous and discontinuous gullies using the gully factor layers mentioned above. First, an assumption was made that gully factor dominance is associated with the extent of gully erosion within a respective class area. To evaluate differences between these gullies at the large catchment scale, the study postulated that a zonal approach is more appropriate than correlation analyses generally utilized in erosion studies. Multiple regression models, for example, tend to suffer from a limited sample design, subjectivity during factor rating, and a large percentage of variability is usually unexplained (Kheir et al., 2007). Due to the spatially thematic configuration of the gully factor layers it was decided to determine the proportion that each of the above-mentioned 5 classes are affected by continuous and discontinuous gully erosion (by means of zonal functions in the Spatial Analyst extension of ArcGIS 9.3).

\section{Results: Gully location map and factor differences}

Figure 2 illustrates the spatial distribution of continuous and discontinuous gully erosion in the catchment. Severe gully erosion is identified mainly in the Tsitsa valley located in the central part of the catchment. Table 2 indicates that 4253 gullies occur in the catchment, directly affecting an area of approximately 5273 ha (1.1\% of the catchment). Only 236 gullies are classified as continuous, yet occupy 2905 ha (55\% of the gullied area). When integrated with drainage networks, gullies reach lengths up to several kilometers and widths up to $100 \mathrm{~m}$. The remaining 4017 gullies are classified as discontinuous. An error matrix (not shown here) was obtained by comparing the gully vector map with observations in the field $(n=200)$. In this context, the overall accuracy of the gully map is $93 \%$. Despite the high level of spatial accuracy, however, manual interpretation is incapable of establishing specific erosion process dynamics and spatial information of the driving forces present (Taruvinga, 2008). 


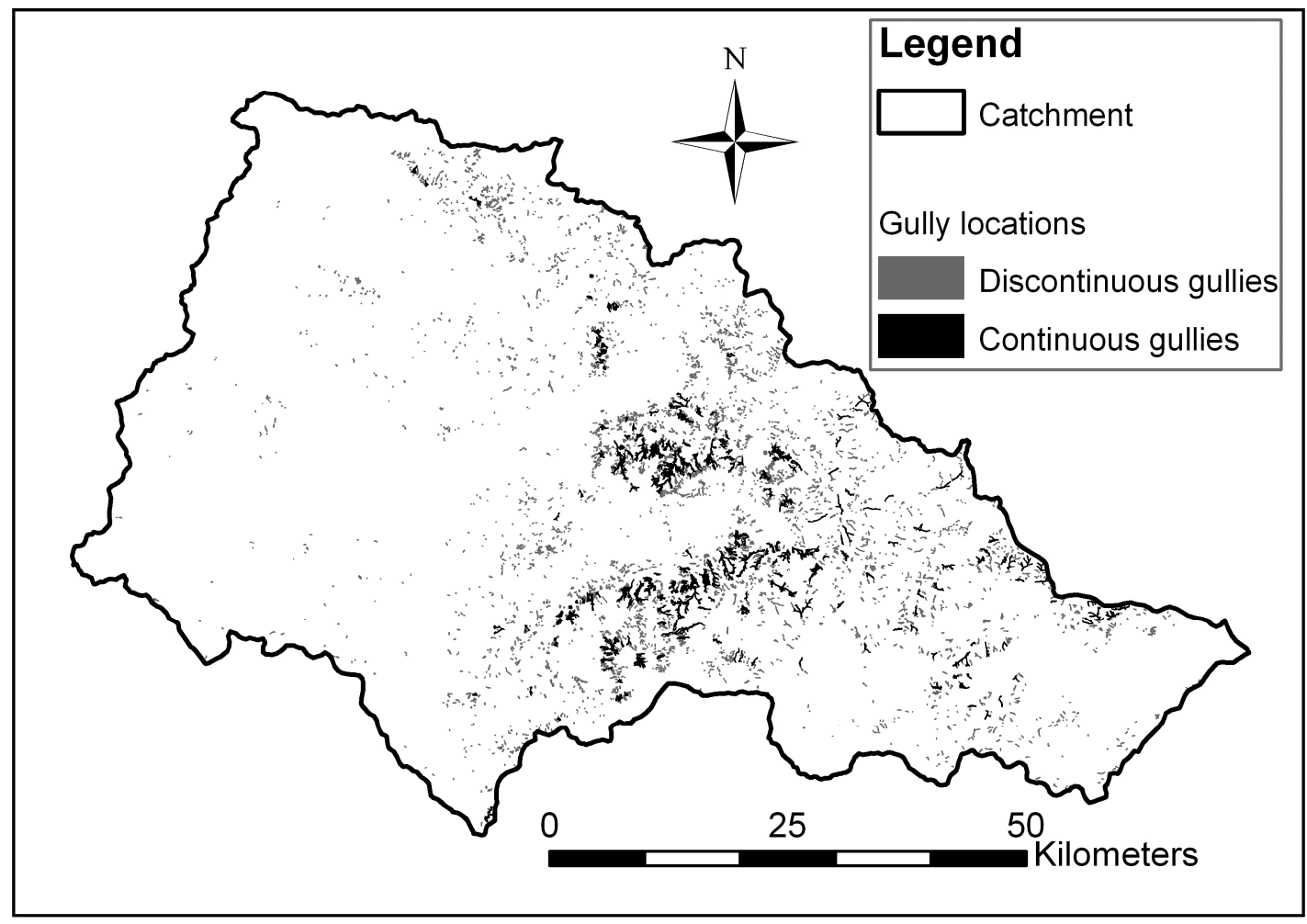

Figure 2: Gully locations map of the catchment in the Eastern Cape Province, SouthAfrica.

Table 2: $\quad$ Gully erosion information for the catchment.

\begin{tabular}{|l|c|c|c|}
\hline Type & Count & Area (ha) & Gullied area (\%) \\
\hline Continuous & 236 & 2905 & 55 \\
\hline Discontinuous & 4017 & 2368 & 45 \\
\hline
\end{tabular}

The second category of information is presented as a series of graphs (see Figure 3), expressing the fractions each class (1-5) affected by continuous gullies (cgs) and discontinuous gullies (dgs). Given that the column height is an indication of gully factor dominance, the most prevalent differences between classes are apparent in Graph-LT, signifying predominant gullying in LT5 (duplex soils). More specifically, approximately $0.0 \%$ and $0.1 \%$ of LT1 (relatively stable soils) is affected by cgs and dgs respectively, whereas approximately $5.2 \%$ and $1.7 \%$ of LT5 is affected by cgs and dgs respectively. Although not as prominent as LT, the other graphs illustrate similar patterns, with fractions 
affected by gully erosion gradually and almost linearly increasing or decreasing from classes 1 to 5 . Furthermore, results indicate that cgs exceed dgs in the higher gully classes, whereas dgs exceed cgs in the lower gully classes (except for Graph-S and Graph-LS). These variations between cgs and dgs warrant further discussion.

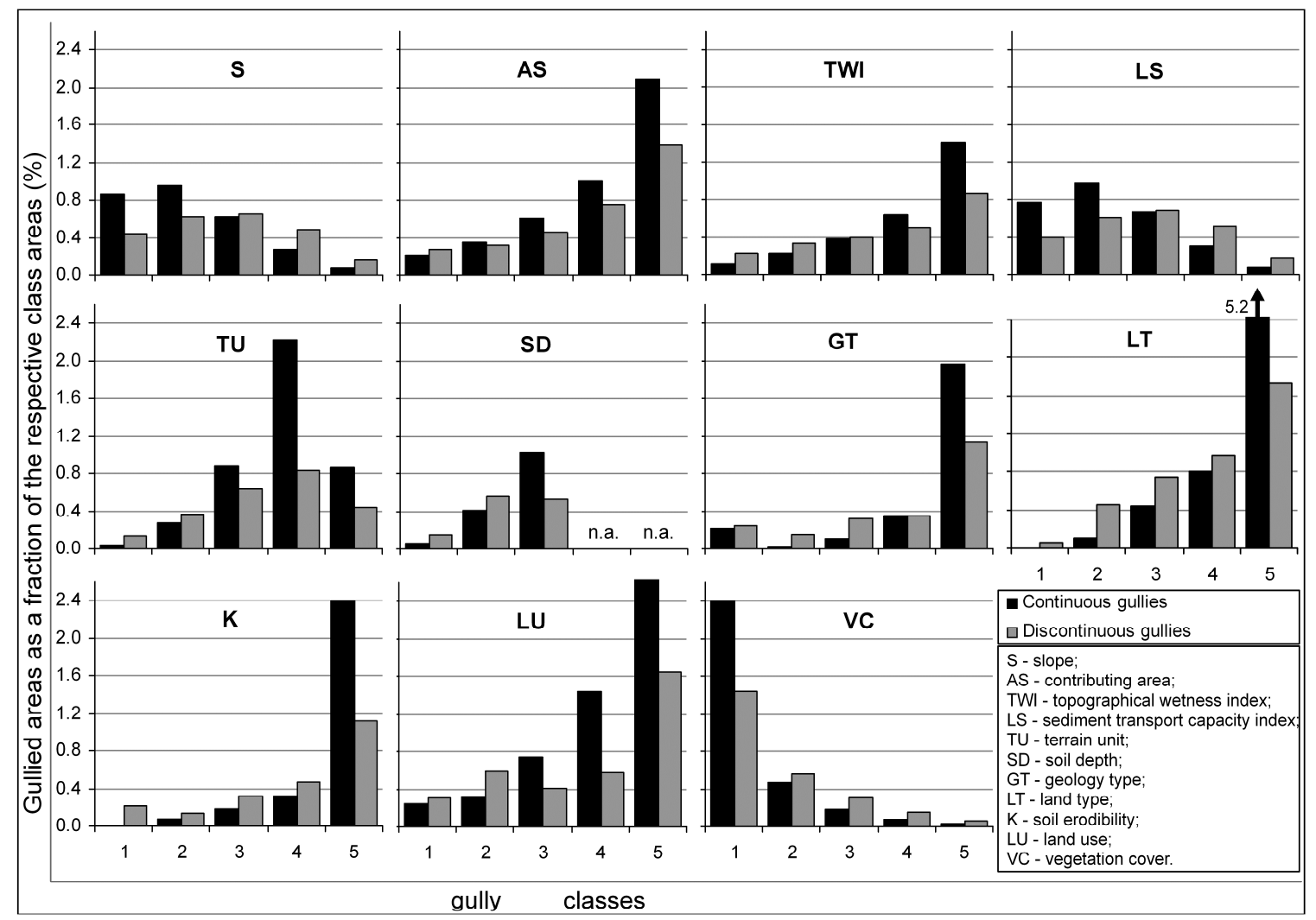

Figure 3: Continuous and discontinuous gullied areas of each class (1-5) as a fraction of the respective class area.

\section{Discussion: Differences between continuous and discontinuous gullies}

Foremost, the high variability of gullied areas or fractions within each class is not surprising due to heterogeneity of the landscape. Despite this variability, it is possible to distinguish a hierarchy in causal factors for gully erosion between continuous gullies (cgs) and discontinuous gullies (dgs). The following discussion describes the gully factors individually but draws some attention to their interdependency. Special attention is given to differences between cgs and dgs. 


\subsection{Topographical factors}

First, gullies in the catchment are mainly located on gentle slopes with gradients less than $10^{\circ}$ as confirmed in other regions of South Africa (Flügel et al., 2003; Kakembo et al., 2009). Although cgs and dgs follow a similar trend in this regard, the current study establishes some significant differences. In particular, cgs (0.9\% of $\mathrm{S} 1)$ are more prominent on gentle slopes than $d g s(0.4 \%$ of $\mathrm{S} 1)$, whereas $d g s(0.2 \%$ of $\mathrm{S} 5)$ are more prominent on steep slopes than cgs ( $0.1 \%$ of $S 5)$. The reason that $d g s$ (the smallest range of gullies) exceed cgs (the largest range of gullies) on rolling slopes is coupled with the reason that gully erosion in the catchment is less severe on steep slopes. Tamene et al. (2006) found in Ethiopia that gully erosion is less severe on steep slopes, probably due to steep areas being less accessible and less exposed to human and livestock disturbances. Another possible reason is provided by Poesen et al. (2003), explaining that the so-called critical drainage area needed for gully initiation decreases as slope steepens. Likewise, Kakembo et al. (2009) observed that gullying in several catchments of the Eastern Cape Province predominantly occurs on gentle slopes where the critical drainage area or upslope contributing area (AS) is high.

Upslope contributing area (AS) is an important topographic variable that is frequently linked with gully development. More specifically, gully development largely depends on high AS values (Kheir et al., 2007). Areas with high AS values have high flow accumulation (number of upslope cells that flow into each cell) used to identify drainage areas and flow paths vulnerable to gully erosion (Desmet et al., 1999). It is therefore not surprising that gullies in the catchment are mainly located on areas with a large AS (>200 $\left.\mathrm{m}^{2}\right)$. It is noteworthy here that, opposite to above-mentioned slope pattern, cgs $(2.1 \%$ of AS5) are more prominent than dgs (1.4\% of AS5) in areas with large AS values, whereas dgs $(0.3 \%$ of AS1) are more prominent than cgs $(0.2 \%$ of AS1) in areas with low AS values. Differences in AS between cgs and dgs can be explained by slope length since dgs have smaller slope lengths with less flow accumulation/concentration of rain water than cgs. Areas with low AS values represent local topographic highs/upper-slopes where flow accumulation required for gully development (especially cgs) is limited. 
Not surprisingly, areas with high AS values also have high topographical wetness index (TWI) values (areas prone to become wet) and vice versa. Similar to the study of Kheir et al. (2007), gully formation in the catchment is particularly favoured in areas with high TWI values $(>0.4)$ representing zones of saturation with high surface soil water along drainage paths where AS is high and slope is low. These saturated areas favour gully formation since the surface soils lose their strength as they become wet. The differences between cgs and dgs are similar to the above-mentioned AS pattern where cgs $(1.4 \%$ of TWI5) exceed $d g s$ ( $0.9 \%$ of TWI5) in areas where TWI is high, whereas dgs $(0.2 \%$ of TWI1) exceed cgs $(0.1 \%$ of TWI1) in areas where TWI is low. Therefore, dgs occur more frequently than cgs in areas where AS is low and slope is high. Areas with low TWI values represent zones with low surface soil water where gully development (especially cgs) is limited.

The sediment transport capacity index (LS) also combines the effects of AS and slope. Areas where LS is high $(>4)$ are vulnerable to erosion due to the generation of sufficient runoff (high AS) with a sufficient level of relief energy (high slope) (Desmet et al., 1999). However, several studies agree that areas with high LS values do not necessarily represent zones where gullies develop (Kheir et al., 2007; Kakembo et al., 2009). Here we confirm that a low proportion of gullied areas in the catchment occur in areas where LS is high. It is noteworthy here that Graph-LS provided in the (Results: Gully Location Map and Factor Differences) Section above appears to be markedly similar to Graph-S, highlighting the distinct predominance of gullies on gentle slopes (as mentioned above). Therefore, for LS, it appears as if slope limits the impact of AS. More specifically, in the catchment more cgs $(0.8 \%$ of LS1) than dgs $(0.4 \%$ of LS1) occur in areas where slope is low, yet AS is high, representing zones of saturation with high surface soil water on footslopes and valley floors. In contrast, more $d g s(0.2 \%$ of LS5) than cgs $(0.1 \%$ of LS5) occur where the slope is relatively high, yet AS is low, representing zones with low surface soil water on topographic highs/upper-slopes.

Several studies in South Africa state that gully development is specially favoured in certain terrain units (TUs), namely footslopes and valley floors (e.g. Descroix et al., 2008; Kakembo et al., 2009). Gully development is favoured in footslopes and valley floors since they represent areas where overland flow is concentrated into preferred pathways of flow 
(Beckedahl and Dardis, 1988), especially concave hollows adjacent to drainage lines, as opposed to upland convex hillslope sections (Kakembo et al., 2009). The present study indicates that footslopes constitute the preferential gully location zone followed (almost equally) by valley floors and concave midslopes. This pattern is especially noticeable for cgs that seems to be expanding from footslopes onto midslopes. More specifically, cgs (4.0\% of TU3-5) exceed dgs (1.9\% of TU3-5) in low hillslope and concave sections, whereas dgs $(0.5 \%$ of TU1-2) exceed cgs (0.3\% of TU1-2) on topographic highs and convex sections. The main reason for this difference is because development of cgs is generally restricted to concave areas along drainage paths where soils are deep (whereas dgs are not).

Although soil depth (SD) is not a topographical factor per se, it is highly correlated with TUs usually increasing downslope or towards the lower hillslope elements (Land Type Survey Staff, 1972-2008). Moreover, gully development also depends on the availability of deep soils (e.g. Descroix et al., 2008; Kakembo et al., 2009). It is therefore not surprising that cgs $(1.0 \%$ of SD3) exceed dgs ( $0.5 \%$ of SD3) where soils are deep, whereas dgs $(0.2 \%$ of SD1) exceed cgs $(0.1 \%$ of SD 1$)$ where soils are shallow. As a result, relatively large fractions of deep soils are affected by gully erosion, especially where footslopes and valleys are filled with erodible soils derived from mudstones.

\subsection{Lithological and pedological factors}

At the regional scale, several authors note that the inherent erodibility of the parent material (geology type - GT) as the overriding erosion risk factor (e.g. Watson and Ramokgopa, 1997; Tamene et al., 2006). In particular, Laker (2004) indicates that in South Africa various mudstones are susceptible to gully erosion mainly due to highly erodible duplex soils derived there from (soils are further discussed below). Figure 3 above confirms the preferential development of gullies on Tarkastad Mudstones with $2.0 \%$ and nearly $1.1 \%$ of GT5 affected by cgs and dgs, respectively. It is noteworthy here that cgs, as well as dgs, on the other GTs are markedly limited. One would expect to find higher proportions of gullies in GT4 since it contains a combination of transported/unconsolidated alluvium and weak sedimentary mudrock that usually give rise to erodible soils (Laker, 2004). One possibility for this discrepancy is that gully development on GT4 is counteracted by other factors such as good vegetation cover. Another reason for the 
preferential development of gullies on Tarkastad Mudstones opposed to the other GTs is linked to the soils derived from these mudstones.

Soils from the Tarkastad Mudstones are notably different from all of the other soils investigated in this study. The most prominent feature of these soils (duplex soils) represented by land types (LTs) in class 5 , is a permeable horizon overlying an impermeable one. As a result, water infiltrates and saturates the top layer above the impermeable one where it moves along as subsurface flow causing tunnel erosion (Beckedahl, 1998). In addition, these soils are usually dispersive and easily lose aggregation. The tunnel network is exposed as gullies where their roofs collapsed. Here we confirm the preferential development of gullies on duplex soils with $5.2 \%$ and $1.7 \%$ of LT5 affected by cgs and dgs, respectively. In contrast, dgs (2.2\% of LT1-4) are more prominent than cgs $(1.4 \%$ of LT1-4) on a variety of relatively stable red to yellow apedal and litho soils. Evidently, gullied soils do not always, or simply, correlate spatially with weak underlying geology. If so, then Graph-LT (Figure 3) would have reflected the same pattern as Graph-GT. Instead, it seems as if the variability between cgs and dgs is largely affected by the high spatial heterogeneity of the LTs and the erodibility of their soils.

It is not surprising that extensively gullied LTs have high soil erodibility $(K)$ values (and vice versa). As expected, the K-graph provided in Figure 3 above is markedly similar to the LTgraph. Once more, the distinction can be made between cgs (2.4\% of $\mathrm{K} 5)$ being more prominent than dgs ( $1.1 \%$ of $\mathrm{K} 5$ ) on highly erodible soils (duplex and dispersive), whereas dgs $(0.7 \%$ of $\mathrm{K} 1-3)$ are more prevalent than cgs $(0.3 \%$ of $\mathrm{K} 1-3)$ on a variety of less erodible soils (that weather more slowly with minimal development). As mentioned above, duplex soils are erodible and favour continuous gully development mainly due to the marked increase in clay content from the topsoil to subsoil horizon. As a result, duplex soils have an abrupt transition between the topsoil and the subsoil with respect to texture, structure and consistence (Samadi et al., 2005). These soils limit intrinsic permeability since water does not move readily into the subsurface matrix, which leads to increased subsurface flow causing tunnel erosion (Beckedahl, 1998). In addition, several studies agree that soils prone to tunnel erosion are usually dispersive and easily lose aggregation as a result of high sodium absorption (e.g. Rienks et al., 2000; Valentin et al., 2005). However, due to the lack of spatial information at a regional scale, the correlation between 
cgs, dgs and sodic soils still needs further investigation. Collectively, all the factors discussed above highlight areas that are intrinsically susceptible to gully development. The last two factors discussed below are important to highlight areas where gully erosion is extrinsically triggered or accelerated by land use and human-induced reduction of the vegetation cover.

\subsection{Land use and vegetation cover}

As indicated by examples worldwide (e.g. Boardman and Foster, 2008; Gutiérrez et al., 2009), gully erosion is often triggered and/or accelerated by inappropriate land use (LU). This trend is confirmed consistently for both sets of gullies. However, cgs (4.9\% of LU3-5) are more prominent than $d g s$ (2.6\% of LU3-5) in cultivated areas and degraded grassland, whereas dgs $(0.9 \%$ of LU1-2) are more prominent than cgs $(0.6 \%$ of LU1-2) in natural vegetated and urban areas. The trend is not surprising since cultivated areas (LU3 and 4) and degraded grassland (LU5) represent areas where the soil is frequently disturbed and gully development (especially cgs) is favoured. Field observations indicate that a relatively large portion of the cultivated and grassland areas in the catchment is affected by gully erosion due to livestock disturbance, including overgrazing and trampling along cattle tracks.

Several studies identify the reduction in vegetation cover (VC) as the main driving factor of gully erosion (e.g. Tamene et al., 2006; Descroix et al., 2008). Figure 3 above indicates that gullies are mainly located in areas with poor VC. More specifically, cgs (2.4\% of VC1) exceed $d g s$ ( $1.4 \%$ of VC1) in areas with poor VC, whereas $d g s(1.1 \%$ of VC2-5) exceed cgs $(0.7 \%$ of VC2-5) in areas with moderate to good VC. Therefore, Figure 3 above illustrates that more vegetation is present in dgs than cgs. A probable reason is related to VC calculations being carried out in a grid-based system that depends on grid-cell resolution (Zhang et al., 2002). For example, the Landsat TM image used to calculate the TSAVI and subsequent VC grid have a coarse resolution of $30 \mathrm{~m}^{2}$ and therefore, small gullies with narrow patches of bare soil are incorrectly imbedded in vegetated areas (Taruvinga, 2008). Since $d g s$ are frequently less than $30 \mathrm{~m}^{2}$ in size, the proportion VC inside gullies at field scale could be overestimated, while the proportion bare soil could be underestimated. 
Given that all zonal calculations in the study are based on a grid system, one of the main limitations of the study is that all outcomes will be subject to a certain degree of error. However, the variability between cgs and dgs caused by various grid-cell resolutions of the gully factor layers is outside the scope of current research and remains to be tested. It appears that the variability between scales is mainly affected by the high spatial heterogeneity of the study area itself. Another limitation worth mentioning here is that the study does not investigate land use history and vegetation conditions prior to gully development (since temporal scales are beyond the scope of this research). Therefore, uncertainties remain to what extent poor vegetation cover contributed to initial gully development in relation to other important contributing factors such as the intrinsic susceptibility of the soil. In effect, gully erosion processes itself can reduce the vegetation cover due to the removal of topsoil, as well as by soil tunneling/collapse. Nevertheless, similar to observations in a number of regions of South Africa (Laker, 2004; Le Roux et al., $2008 \mathrm{~b}$ ), it is postulated that a combination of overgrazing and susceptible mudstones proves to be key factors that consistently determine the development of cgs and dgs in the catchment.

\section{Conclusions and recommendations}

Factors leading to the development of gullies in the catchment are consistent with other studies. However, previous research has not yet explicitly quantified differences in factor dominance between large continuous gullies (cgs) and relatively small discontinuous gullies (dgs). This factorial analysis contributes to perspectives on gully development by quantifying the differences or extent in factor dominance between cgs and dgs. The study indicates the complexity of a series of collective factors that are not identical between cgs and dgs. Factors leading to the development of cgs are gentle slopes in zones of saturation along drainage paths with a large contributing area, erodible duplex soils derived from mudstones, and poor vegetation cover due to overgrazing. When integrated with drainage networks, gullies expand from valley floors and footslopes onto concave midslopes where the soils are deep. Compared to continuous gully conditions, more dgs occur on rolling slopes where the surface becomes less frequently saturated with a smaller contributing area and where soils are more stable and shallow. These conditions prevent dgs from expanding extensively or from becoming continuous. However, they might still be 
active, as reported by Ndomba et al. (2009) for dgs in a catchment northeast of Tanzania. Further refinement will be possible given additional research, including investigation of the effect of land use history and vegetation conditions prior to gully development (e.g. Kakembo et al., 2009), distinction between active and passive gullies using a combination of different optical and multi-temporal data (Ndomba et al., 2009), and modeling gully erosion rates for representative test gullies and then averaging the results over the areas of active gully erosion (Flügel et al., 2003).

Separation of gullies into these two groups is consistent with the findings of Descroix et al. (2008). The main difference to previous multi-scale studies such as Descroix et al. (2008) and Sonneveld et al. (2005) is specific quantification of the differences or extent in gully factor dominance between cgs and $d g s$. Some of the most prevalent differences between the two groups are apparent for the terrain unit and soil factors (land types and soil erodibility). A marked distinction can be made between large cgs favoured on footslopes with highly erodible soils (duplex and dispersive) and small $d g$ s prevalent on a variety of terrain units with less erodible soils (that weather more slowly with minimal development). A combination of overgrazing and susceptible mudstones proves to be key factors that consistently determine the development of cgs and dgs.

Understanding the significance of gully controlling factors from field to catchment scale enables site- and scale-specific management intervention. For example, due to limited financial resources it will not be feasible to rehabilitate cgs with large and expensive structures at the catchment scale. However, it is imperative to minimize their current expansion from footslopes onto concave midslopes with site-specific construction of structures and protecting the vegetation from overgrazing (especially upslope along drainage paths situated on duplex soils). In addition to rehabilitating existing gullies, the identification of currently vegetated or gully-free areas susceptible to continuous and/or discontinuous gully development can also be achieved (not shown here - but estimated at approximately 560 and 6700 ha, respectively). Appropriate strategies then need to be designed for susceptible areas in order to protect the current vegetation cover. 


\section{Acknowledgements}

Numerous colleagues at the Agricultural Research Council - Institute for Soil, Climate and Water (ARC-ISCW) have assisted the research efforts including Mr. H.L. Weepener, Mrs. K. Middleton, Mr. J.L. Schoeman, Dr. H.J. Smith and Mr. J.C.L. Potgieter, as well as literature provided by Mrs. R. van Dyk. Special thanks to Mr. Z.E. Mashimbye for digitizing some of the gullies utilized in the study. Thanks to Mr. H.M. Van Den Berg of IRIS International for valuable advice. The authors are thankful for research funding from the ARC-ISCW, as well as Mr. D.J. Pretorius and his colleagues at the Department of Agriculture Forestry and Fisheries (DAFF), Directorate Land Use and Soil Management. The paper benefited greatly from the comments by two referees on an earlier version.

\section{References}

Beckedahl HR. 1998. Aspects of subsurface erosion phenomena in eastern southern Africa. Peterman's Geographische Mitteilungen (Supplement) 245: 213.

Beckedahl HR, Dardis GF. 1988. The role of artificial drainage in the development of soil pipes and gullies, some examples from Transkei, southern Africa. In: Dardis GF, Moon BP. (eds.). Geomorphological studies in southern Africa. Balkema: Rotterdam. pg 229-245.

Boardman J, Foster I. 2008. Badland and gully erosion in the Karoo, South Africa. Journal of Soil and Water Conservation 63(4): 121A-125A.

Council for Geoscience. 2007. Geological data 1:250 000. Council for Geoscience: Pretoria, South Africa.

Descroix L, González Barrios JL, Viramontes D, Poulenard J, Anaya E, Esteves M, Estrada J. 2008. Gully and sheet erosion on subtropical mountain slopes: Their respective roles and the scale effect. Catena 72: 325-339.

Desmet PJJ, Poesen J, Govers G, Vandaele K. 1999. Importance of slope gradient and contributing area for optimal prediction of the initiation and trajectory of ephemeral gullies. Catena 37: 377-392.

Elwell HA. 1976. Natal Agricultural Research Bulletin No 7, Soil Loss Estimator for Southern Africa. Department of Agricultural Technical Services: Natal, South Africa.

Evans IS. 1979. An integrated system of terrain analysis and slope mapping. Final report on grant DA-ERO-591-73-G0040. University of Durham: England. http://www.soi.city.ac.uk/ jwo/phd.

Flügel W, Märker M, Moretti S, Rodolfi G, Sidrochuk A. 2003. Integrating geographical information systems, remote sensing, ground truthing and modeling approaches for regional erosion classification of semi-arid catchments in South Africa. Hydrological Processes 17: 929-942.

GISCOE. 2001. GISCOE Digital Terrain Models. GIMS: Midrand, South Africa. 
Gutiérrez AG, Schnabel S, Felicísimo AM. 2009. Modelling the occurrence of gullies in rangelands of southwest Spain, Earth Surface Processes \& Landforms 34: 1894-1902.

Kakembo V, Xanga WW, Rowntree K. 2009. Topographic thresholds in gully development on the hillslopes of communal areas in Ngqushwa Local Municipality, Eastern Cape, South Africa. Geomorphology 110: 188-194.

Kheir RB, Wilson J, Deng Y. 2007. Use of terrain variables for mapping gully erosion susceptibility in Lebanon. Earth Surface Processes \& Landforms 32: 1770-1782.

Kheir RB, Chorowicz J, Abdallah C, Dhont D. 2008. Soil and bedrock distribution estimated from gully form and frequency: A GIS-based decision-tree model for Lebanon. Geomorphology 93: 482492.

Killick DJB. 1963. An account of the plant ecology of the Cathedral Peak area of the Natal Drakensberg, Memoirs of the Botanical Survey of South Africa, 32. Department of Agricultural Technical Service: Pretoria, South Africa.

Kirkby MJ, Bracken LJ. 2009. Gully processes and gully dynamics. Earth Surface Processes \& Landforms 34: 1841-1851.

Laker MC. 2004. Advances in soil erosion, soil conservation, land suitability evaluation and land use planning research in South Africa. South African Journal of Plant and Soil 21: 345-368.

Land Type Survey Staff. 1972-2008. Land Types of South Africa: Digital Map (1:250 000 scale) and Soil Inventory Databases. ARC-Institute for Soil, Climate and Water: Pretoria, South Africa.

Le Roux JJ, Mashimbye ZE, Weepener HL, Newby TS, Pretorius DJ. 2008a. Erosion status of priority tertiary catchment areas identified by the Soil Protection Strategy of the Department of Agriculture. ISCW Report No. GW/A/2008/17. ARC-Institute for Soil, Climate and Water: Pretoria, South Africa.

Le Roux JJ, Morgenthal TL, Malherbe J, Sumner PD, Pretorius DJ. 2008b. Water erosion prediction at a national scale for South Africa. Water SA 34(3): 305-314.

Low AB, Rebelo AG. 1998. Vegetation of South Africa, Lesotho and Swaziland. Department of Environmental Affairs and Tourism: Pretoria, South Africa.

Martinez-Casasnovas JA. 2003. A spatial information technology approach for the mapping and quantification of gully erosion. Catena 50: 293-308.

Martinez-Casasnovas JA, Anton-Fernandez C, Ramos MC. 2003. Sediment production in large gullies of the Mediterranean area (NE Spain) from high-resolution digital elevation models and geographical information systems analysis. Earth Surface Processes and Landforms 28: 443-456.

Mitasova H, Zlocha M, Hofierka J, Iverson LR. 1996. Modelling topographic potential for erosion and deposition using GIS. International Journal of Geographical Information Systems 10(5): 629641.

National Land Cover. 2000. National Land Cover 2000, Unpublished. ARC-Institute for Soil, Climate and Water; Council for Scientific and Industrial research: Pretoria, South Africa.

Ndomba PM, Mtalo F, Killingtveit A. 2009. Estimating gully erosion contribution to large catchment sediment yield rate in Tanzania. Physics and Chemistry of the Earth 34: 741-748. 
Poesen J, Nachtergaele J, Verstraeten G, Valentin C. 2003. Gully erosion and environmental change: importance and research needs. Catena 50: 91- 133.

Rienks SM, Botha GA, Hughes JC. 2000. Some physical and chemical properties of sediments exposed in a gully (donga) in northern KwaZulu-Natal, South Africa and their relationship to the erodibility of the colluvial layers. Catena 39: 11-31.

Rodriguez E, Morris CS, Belz JE, Chapin EC, Martin JM, Daffer W, Hensley S. 2005. An assessment of the SRTM topographic products, Technical Report JPL D-31639. Jet Propulsion Laboratory: Pasadena, USA.

Samadi M, Germishuyse T, Van der Walt M. 2005. Understanding South African Soils. ARC Institute for Soil, Climate and Water: Pretoria, South Africa.

Schmidt J, Evans IS, Brinkmann J. 2003. Comparison of polynomial models for land surface curvature calculation. International Journal of Geographical Information Science 17(8): 797-814.

Sonneveld MPW, Everson TM, Veldkamp A. 2005. Multi-scale analysis of soil erosion dynamics in Kwazulu-Natal, South Africa. Land Degradation and Development 16: 287-301.

Tamene L, Park SJ, Dikau R, Vlek PLG. 2006. Analysis of factors determining sediment yield variability in the highlands of northern Ethiopia. Geomorphology 76: 76- 91.

Tarboton DG. 2004. TAUDEM. Terrain Analysis using digital elevation models. Utah State University. Logan, Utah, USA.

Taruvinga K. 2008. Gully mapping using remote sensing: Case study in KwaZulu-Natal, South Africa, MSc thesis (Geography). Waterloo University: Canada.

Valentin C, Poesen J, Li Y. 2005. Gully erosion: Impacts, factors and control. Catena 63: 132-153.

Van Den Berg HM, Weepener HL. 2009. Development of spatial modelling methodologies for semidetailed soil mapping, primarily in support of curbing soil degradation and the zoning of high potential land. ISCW Report No. GW/A/2009/01. ARC-Institute for Soil, Climate and Water: Pretoria, South Africa.

Vrieling A. 2006. Satellite remote sensing for water erosion assessment: A review. Catena 65: 2-18.

Vrieling A, Rodrigues SC., Bartholomeus, H. and Sterk, G., 2007. Automatic identification of erosion gullies with ASTER imagery in the Brazilian Cerrados. International Journal of Remote Sensing 28(12): 2723-2738.

Watson HK, Ramokgopa R. 1997. Factors influencing the distribution of gully erosion in KwaZuluNatal's Mfolozi catchment - land reform implications. South African Geographical Journal, 79(1): 27-34.

Wischmeier WH, Smith DD. 1978. Predicting rainfall erosion losses, a guide to conservation planning. U.S. Department of Agriculture, Agricultural Handbook No 537.

Wilson JP, Gallant JC. 2000. Digital terrain analysis; In: Wilson JP, Gallant JC. (eds.). Terrain analysis. John Wiley \& Sons, Inc: New York. pg 1-27. 
Zhang X, Drake N, Wainwright J. 2002. Scaling land surface parameters for global-scale soil erosion estimation. Water Resources Research 38(9): 191-199. 